\title{
Synthesis, Crystal Structures, and Magnetic Properties of Ternary M(II)-Dicyanamide-hydroxypyridine Complexes
}

\author{
Ling-Ling Zheng \\ Guangzhou Vocational College of Technology \& Business, 511442, China \\ Correspondence should be addressed to Ling-Ling Zheng; zsuzhengll@yahoo.com.cn
}

Received 29 March 2013; Accepted 30 April 2013

Academic Editor: Henryk Kozlowski

Copyright ( 2013 Ling-Ling Zheng. This is an open access article distributed under the Creative Commons Attribution License, which permits unrestricted use, distribution, and reproduction in any medium, provided the original work is properly cited.

\begin{abstract}
Three two-dimensional (2D) and 3D supramolecular coordination architectures based on ternary M(II)-dicyanamide-2-hydroxypyridine systems, $\left[\mathrm{Co}(\mathrm{hmpH})_{2}(\mathrm{dca})_{2}\right](\mathbf{1}),\left[\mathrm{Cu}(\mathrm{hmpH})_{2}(\mathrm{dca})_{2}\right](\mathbf{2})$, and $\left[\mathrm{Mn}(\mathrm{hepH})_{2}(\mathrm{dca})_{2}\right](\mathbf{3})(\mathrm{dca}=$ dicyanamide, $\mathrm{hmpH}=$ 2-(hydroxymethyl)pyridine, hepH = 2-(hydroxyethyl)pyridine), have been synthesized. 1 is a mononuclear Co(II) complex. The mononuclear units are interlinked into a $2 \mathrm{D}(4,4)$ hydrogen-bonded layer via $\mathrm{O}-\mathrm{H} \cdots \mathrm{N}$ hydrogen bonds between the hydroxyl groups and the noncoordinating nitrile ends. These $2 \mathrm{D}$ layers are further extended into a $3 \mathrm{D}$ supramolecular architecture via the interlayer pyridyl-pyridyl stacking interaction. 2 has a $1 \mathrm{D}$ coordination chain structure formed by the double $\mu_{1,5}$-dca bridged dinuclear $\left[\mathrm{Cu} 2\left(\mu_{1,5}-\mathrm{dca}\right)_{2}(\mathrm{hmpH})_{2}\right]$ unit and the $\mu_{1,3}$-dca bridges via weak $\mathrm{Cu}-\mathrm{N}$ coordination, and these $1 \mathrm{D}$ coordination chains are further extended into 2D hydrogen-bonded layers via strong $\mathrm{O}-\mathrm{H} \cdots \mathrm{N}$ hydrogen-bonding interaction between the hydroxyl groups and the noncoordinating nitrile ends. 3 is a $2 \mathrm{D}(4,4)$ coordination network made of $1 \mathrm{D}\left[\mathrm{Mn}(\mathrm{hepH})\left(\mu_{1,5}-\mathrm{dca}\right)\right]$ helical chain units and interchain double $\left(\mu_{1,5}\right.$-dca) bridges. Pairs of $\left[\mathrm{Mn}(\mathrm{hepH})\left(\mu_{1,5}-\mathrm{dca}\right)\right]$ helical chains are interlinked by the double $\left(\mu_{1,5}{ }^{-}\right.$ $\mathrm{dca}$ ) bridges into a racemic coordination layer structure, which is further extended into a 3D hydrogen-bonded network. Magnetic studies reveal that weak antiferromagnetic exchange occurs in 3.
\end{abstract}

\section{Introduction}

Since the pioneering reports of Robson and coworkers in $1990[1,2]$, this realm of crystal engineering is growing interest, and great efforts have been devoted to the assembly of supramolecular systems of organic molecular solids and coordination polymers through hydrogen bonds and or coordination bonds, with the resultant crystalline materials having a wide range of potential applications, such as electronic, magnetic, optical, absorbent, and catalytic materials [3-29]. In recent years, much attention has been devoted to dicyanamide-anion- (dca-) bridged coordination polymers [30-42] for the large variety of magnetic properties, especially the $\alpha-\mathrm{M}(\mathrm{dca})^{2}$ series of compounds, which have isomorphous rutile-like structure, display ferromagnetism (Co, Ni) [43-46], spin-canted antiferromagnetism (Cr, Mn, $\mathrm{Fe})[47,48]$, and paramagnetism $(\mathrm{Cu})[45,46]$. Of further importance, from a structural perspective, when auxiliary $\mathbf{L}$ ligands are introduced to the ternary $\mathrm{M}^{\mathrm{II}}$-dca-L systems, different coordination architectures, such as mononuclear and dinuclear compounds [49], 1D chains [50-58], 2D (4,4) or $(6,3)$ [59-63] sheets, and 3D network topologies [6467], could be constructed (Scheme 1). Interestingly, interesting in situ nucleophilic addition reactions were observed between dca and the auxiliary ligands [68-73]. On the other hand, weak interactions such as hydrogen bonding and $\pi$ $\pi$ interactions play an important role for construction of high-dimensional supramolecular systems [74-76]. From the viewpoint of rational network design, if the coligand can combine multifunctions such as coordination, hydrogenbond donor or acceptor, and aromaticity, many interesting supramolecular architectures will be constructed.

In this work, two 2-hydroxypyridines, 2-(hydroxymethyl) pyridine $(\mathrm{hmpH})$, and 2-(hydroxyethyl) pyridine (hepH) were chosen as the auxiliary ligands to the M(II)-dca-L systems to realize this rational crystal engineering for the following reasons: (1) hmpH and hepH can act as chelating ligand; (2) the hydroxyl groups of hmpH and hepH may act as the hydrogen bond donors, which generate strong hydrogen bond with the amide nitrogen atom of the dca 
<smiles></smiles><smiles>CN(C#N)C#N</smiles><smiles></smiles><smiles>[125IH]</smiles><smiles>CN(C#N)C#N</smiles><smiles></smiles><smiles></smiles>

Scheme 1: Schematic showing the coordination modes of dca.

ligand. We report herein three ternary supramolecular architectures $\left[\mathrm{Co}(\mathrm{dca})_{2}(\mathrm{hmpH})_{2}\right](\mathbf{1}),\left[\mathrm{Cu}(\mathrm{dca})_{2}(\mathrm{hmpH})_{2}\right]$ (2), and $\left[\mathrm{Mn}(\mathrm{dca})_{2}(\mathrm{hepH})\right]_{n}(\mathbf{3})$ obtained by this strategy.

\section{Experimental}

2.1. Materials and General Methods. The reagents and solvents employed were commercially available and used as received without further purification. The $\mathrm{C}, \mathrm{H}$, and $\mathrm{N}$ microanalyses were carried out with an Elementar Vario-EL CHNS elemental analyzer. The FT-IR spectra were recorded from $\mathrm{KBr}$ pellets in the range $4000-400 \mathrm{~cm}^{-1}$ on a Bruker TENSOR27 spectrometer. Variable-temperature magnetic susceptibility measurements were made using a SQUID magnetometer MPMS XL-7 (Quantum Design) at 0.1 T for 3. The diamagnetic correction for each sample was determined from Pascal's constants.

\subsection{Synthesis}

2.2.1. Synthesis of $\left[\mathrm{Co}(\mathrm{hmpH})_{2}(\mathrm{dca})_{2}\right]$ (1). Amethanol solution $(10 \mathrm{~mL})$ of $\mathrm{Co}\left(\mathrm{NO}_{3}\right)_{2} \cdot 6 \mathrm{H}_{2} \mathrm{O}(145 \mathrm{mg}, 0.5 \mathrm{mmol})$ was added dropwise to a $\mathrm{CH}_{3} \mathrm{OH} / \mathrm{H}_{2} \mathrm{O}$ solution $(20 \mathrm{~mL})$ containing sodium dicyanamide $(89 \mathrm{mg}, 1.0 \mathrm{mmol})$ and $\mathrm{hmpH}(109 \mathrm{mg}, 1.0 \mathrm{mmol})$. A red solution formed on addition of metal salt to the ligands. The mixture solution was filtered and solvent evaporated at room temperature. Well-shaped red block crystals of 1 were obtained within 1 week in $62 \%$ yield. Anal. calcd. for $\mathrm{C}_{16} \mathrm{H}_{14} \mathrm{CoN}_{8} \mathrm{O}_{2}$ : C, 46.95; H, 3.45; N, 27.38\%. Found: C, 46.53; H, 3.52; N, 27.21\%. IR: $3081 \mathrm{~m}, 2215 \mathrm{vs}, 1602 \mathrm{~m}, 1561 \mathrm{~m}, 1483 \mathrm{~s}, 1432 \mathrm{~m}, 1385 \mathrm{w}, 1347 \mathrm{w}$, 1298vs, 1250s, 1142vs, 1081m, 988w, 861m, 754m, 675m, 646w, 612w, 450vw.
2.2.2. Synthesis of $\left[\mathrm{Cu}(\mathrm{hmpH})_{2}(\mathrm{dca})_{2}\right]$ (2). Amethanol solution $(10 \mathrm{~mL})$ of $\mathrm{Cu}\left(\mathrm{NO}_{3}\right)_{2} \cdot 3 \mathrm{H}_{2} \mathrm{O}(121 \mathrm{mg}, 0.5 \mathrm{mmol})$ was added dropwise to a $\mathrm{CH}_{3} \mathrm{OH} / \mathrm{H}_{2} \mathrm{O}$ solution $(20 \mathrm{~mL})$ containing sodium dicyanamide $(89 \mathrm{mg}, 1.0 \mathrm{mmol})$ and $\mathrm{hmpH}$ (109 mg, $1.0 \mathrm{mmol}$ ). A blue solution formed on addition of metal salt to the ligands. The mixture was filtered and solvent evaporated at room temperature. Well-shaped blue block crystals of 2 were obtained within 1 week in $83 \%$ yield. Anal. calcd. for $\mathrm{C}_{10} \mathrm{H}_{7} \mathrm{CuN}_{7} \mathrm{O}$ : C, 39.41; H, 2.32; N, 32.17\%. Found: C, 39.32; H, 2.41; N, 32,03\%. IR: 3706w, 3429m, 3074w, 2855m, 2378s, 2214vs, 1613s, 1571m, 1485m, 1440s, 1366m, 1292m, $1223 \mathrm{vw}, 1159 \mathrm{vw}, 1092 \mathrm{vs}, 931 \mathrm{vw}, 821 \mathrm{vw}, 762 \mathrm{~s}, 722 \mathrm{~m}, 673 \mathrm{~s}, 623 \mathrm{~s}$, 533m, 483w, 438m.

2.2.3. Synthesis of $\left[\mathrm{Mn}(\text { hepH })_{2}(d c a)_{2}\right]_{n}$ (3). hepH (123 mg, $1.0 \mathrm{mmol}$ ), dissolved in a minimum amount of methanol, was added to an aqueous solution containing $\mathrm{MnCl}_{2} \cdot 4 \mathrm{H}_{2} \mathrm{O}$ (99 $\mathrm{mg}, \quad 0.5 \mathrm{mmol}$ ) and sodium dicyanamide (89 mg, $1.0 \mathrm{mmol}$ ). Block colorless crystals of 3 were grown after 5 days. Yield: ca 74\%. Anal. Calcd. for $\mathrm{C}_{11} \mathrm{H}_{9} \mathrm{MnN}_{7} \mathrm{O}: \mathrm{C}$, 42.59; H, 2.92; N, 31.61\%. Found: C, 41.84; H, 3.07; N, 31.23\%. IR: 3597w, 3541w, 3286m, 3081w, 2954vw, 2901vw, 2310m, $2273 \mathrm{~m}, 2242 \mathrm{~m}, 2177 \mathrm{~s}, 1606 \mathrm{~s}, 1571 \mathrm{~m}, 1488 \mathrm{~s}, 1440 \mathrm{~s}, 1419 \mathrm{w}$, $1369 \mathrm{~s}, 1308 \mathrm{vs}, 1249 \mathrm{vw}, 1155 \mathrm{w}, 1107 \mathrm{~m}, 1075 \mathrm{~m}, 1029 \mathrm{~s}, 940 \mathrm{~m}$, 890vw, 866w, 759m, 658w, 640vw, 579w, 515m, 451vw, 416vw.

2.3. X-Ray Crystallographic Study. Single-crystal data of 13 were collected at 293(2) K on a Bruker Smart 1000 CCD diffractometer with Mo Ka radiation $(\lambda=0.71073 \AA)$. All empirical absorption corrections were applied using the SADABS program [77]. The structure was solved using direct method, which yielded the positions of all nonhydrogen atoms. These were refined first isotropically and then anisotropically. All calculations were performed using the SHELXTL programs [78]. The crystallographic data for 13 are summarized in Table 1 . The selected bond lengths and angles are listed in Table 2.

CCDC 711609-711611 contain the supplementary crystallographic data for this paper. These data can be obtained free of charge from the Cambridge Crystallographic Data Centre.

\section{Results and Discussion}

3.1. Synthesis and Characterization. Air-stable complexes 1-3 were obtained from the reactions of metal(II) salts, $\mathrm{Na}$ (dca), and 2-hydroxypyridine-type ligands (Scheme 2), in which the hydroxypyridines act as chelating ligands. Moreover, the products are independent of the ligand-to-metal ratios.

In contrary, under base condition, 2-hydroxypyridinetype ligands, such as $\mathrm{hmpH}$, hepH, and 2,6-pyridinedimethanol, have been found to act as bridging ligands to generate some fascinating polynuclear metal-clusters [79-82] and the extended 1D or 2D metal cluster-based coordination polymers with dca as bridges in recent years [83-85].

The IR spectra of $\mathbf{1}-\mathbf{3}$ are quite similar. They all show strong absorptions in the range of $2310-2100 \mathrm{~cm}^{-1}$, which correspond to the $\nu_{\mathrm{s}}+\nu_{\text {as }}(\mathrm{C} \equiv \mathrm{N}), \nu_{\text {as }}(\mathrm{C} \equiv \mathrm{N})$, and $\nu_{\mathrm{s}}(\mathrm{C} \equiv \mathrm{N})$ modes of the dca ligand [86]. 


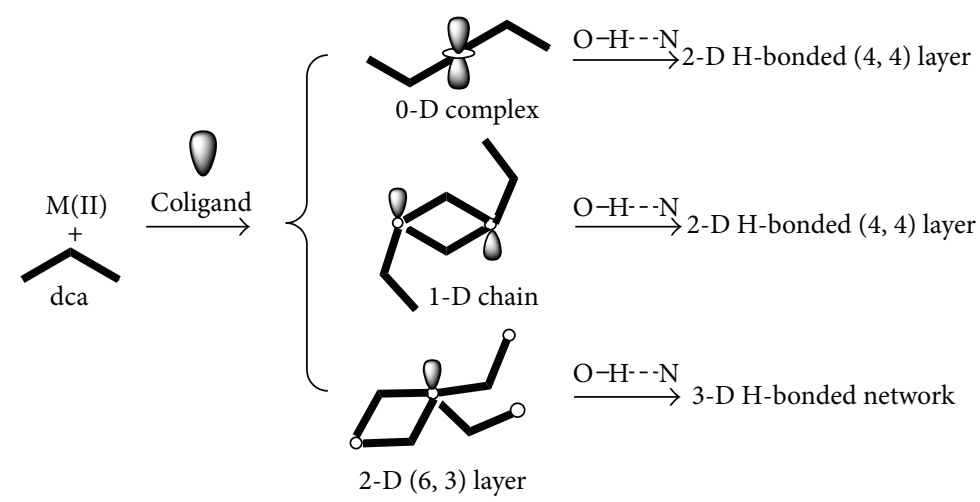

SCHEme 2: Schematic showing the synthesis of complexes 1-3.

TABLE 1: Crystal and structure refinement for compounds 1-3.

\begin{tabular}{lccc}
\hline Compound & $\mathbf{1}$ & $\mathbf{2}$ & $\mathbf{3}$ \\
\hline Formula & $\mathrm{C}_{16} \mathrm{H}_{14} \mathrm{CoN}_{8} \mathrm{O}_{2}$ & $\mathrm{C}_{10} \mathrm{H}_{7} \mathrm{CuN}_{7} \mathrm{O}$ & $\mathrm{C}_{11} \mathrm{H}_{9} \mathrm{MnN}_{7} \mathrm{O}$ \\
Formula mass & 409.28 & 304.77 & 310.19 \\
Cryst. syst. & Monoclinic & Triclinic & Monoclinic \\
Space group & $C 2 / c$ & $P-1$ & $P 2_{1} / c$ \\
$a(\AA)$ & $18.5091(19)$ & $7.4025(10)$ & $12.828(3)$ \\
$b(\AA)$ & $7.8876(8)$ & $7.5004(9)$ & $8.0561(18)$ \\
$c(\AA)$ & $14.0965(15)$ & $11.4982(15)$ & $12.982(3)$ \\
$\alpha\left(^{\circ}\right)$ & 90.00 & $78.557(2)$ & 90.00 \\
$\beta\left(^{\circ}\right)$ & $118.124(2)$ & $89.574(2)$ & $103.162(5)$ \\
$\gamma\left(^{\circ}\right)$ & 90.00 & $72.701(2)$ & 90.00 \\
$V\left(\AA^{3}\right)$ & $1815.0(3)$ & $596.50(13)$ & $1306.4(5)$ \\
$Z$ & 4 & 2 & 4 \\
$T(\mathrm{~K})$ & $293(2)$ & $293(2)$ & $293(2)$ \\
$F(000)$ & 836 & 306 & 628 \\
$D c\left(\mathrm{~g} \mathrm{~cm}{ }^{-3}\right)$ & 1.498 & 1.697 & 1.577 \\
$\left.\mu(\mathrm{mm})^{-1}\right)$ & 0.975 & 1.834 & 1.017 \\
Final $R$ indexes & $0.0319,0.0832$ & $0.0391,0.0926$ & $0.0488,0.1032$ \\
{$[I>2 \sigma(I)]$} & & & $0.0955,0.1219$ \\
Final $R$ indexes & $0.0345,0.0847$ & $0.0449,0.0963$ & \\
{$[$ all data] } & & & \\
\hline$R_{1}=\sum\left\|F_{o}|-| F_{c}\right\| / \sum\left|F_{o}\right|, w R_{2}=\left[\sum w\left(F_{o}^{2}-F_{c}^{2}\right)^{2} / \sum w\left(F_{o}^{2}\right)^{2}\right]^{1 / 2}$ &.
\end{tabular}

3.2. Structure Description. Compound $\mathbf{1}$ crystallizes in monoclinic space group $C 2 / c$ with the asymmetric unit consisting of half formula unit. The Col ion lies on a special position and adopts a greatly distorted octahedral environment (Figure 1(a)) ligated by two $\mathrm{N}$ atoms $(\mathrm{Co}-\mathrm{N}=2.114(2) \AA)$ and two $\mathrm{O}$ atoms $(\mathrm{Co}-\mathrm{O}=2.165(7) \AA)$ from two chelate $\mathrm{hmpH}$ ligands and two nitrile $\mathrm{N}(\mathrm{Co}-\mathrm{N}=2.077(2) \AA)$ atoms from two trans-dca ligands. The dca ligand is in $\mu_{1}$ coordination mode and acts as a terminal ligand. The dca anions adopt nonlinear bonding configurations about the Co ions with C1$\mathrm{N} 1-\mathrm{Col}=162.08(3)^{\circ}$.

These mononuclear units are further cross-linked by strong $\mathrm{N} \cdots \mathrm{H}-\mathrm{O}[87]$ hydrogen-bonding interaction between hydroxyl groups and uncoordinated nitrile ends of the dca ligands $\left(\mathrm{O} 1 \cdots \mathrm{N} 3 b=2.728(2) \AA\right.$; O1- $\left.\mathrm{H} 1 \mathrm{O} \cdots \mathrm{N} 3 b=169.0^{\circ}\right)$ to form a $2 \mathrm{D}$ sheet with $(4,4)$ topology, as shown in Figure 1(b).

Analysis of the crystal packing of 1 shows that these sheets again interdigitate to form 3D supramolecular architecture (Figure 1(c)), with the average interplanar distance between pyridine rings being ca. $3.55 \AA$.

Compound 2 crystallizes in triclinic $P-1$ space group with the asymmetric unit containing half formula unit. The copper atoms are coordinated to one chelating hmpH ligand, coordinating via the pyridyl nitrogen atom donor $(\mathrm{Cu}-\mathrm{N}=1.988(2) \AA)$ and hydroxyl oxygen atom $(\mathrm{Cu}-$ $\mathrm{O}=1.986(2) \AA)$, two bridging $\mu_{1,5}$-dca anions $(\mathrm{Cu}-\mathrm{N}=$ $1.968(3)$ and 2.323(3) $\AA)$, and one "terminal" dca anion $(\mathrm{Cu}-$ $\mathrm{N}=1.965(3) \AA)$. The coordination geometry of $\mathrm{Cu}^{\mathrm{II}}$ center $\left(\mathrm{CuN}_{4} \mathrm{O}\right)$ can be described as a square pyramid. The N3 atom occupied the apical position. Similar to 1 , the dca anions adopt nonlinear bonding configurations about $\mathrm{Cu}$ ion with $\mathrm{C} 2-\mathrm{N} 3-\mathrm{Cu}=151.5(2)^{\circ}, \mathrm{C} 2-\mathrm{N} 1-\mathrm{Cu}=161.7(2)^{\circ}$, and $\mathrm{C} 3-\mathrm{N} 4-\mathrm{Cu}=165.4(2)^{\circ}$. The bridging dca anions extend the $\mathrm{Cu}^{\mathrm{II}}$ centers to generate a dinuclear with double dca bridges (Figure 2(a)). The $\mathrm{Cu} \cdots \mathrm{Cu}$ separation is 7.311(2) $\AA$. These dinuclear units are further linked by weak $\mathrm{Cu}-\mathrm{N}$ interactions (2.866 (3) $\AA$ ) between the copper atoms and "uncoordinated" amide nitrogen atoms of the terminal dca anions to form double dca bridges $(\mathrm{Cu} \cdots \mathrm{Cu}=5.827(6) \AA)$. The $\mathrm{Cu} \cdots \mathrm{Cu}$ separations through $1,3-\mu_{2}$-dca are significantly shorter than those through $1,5-\mu_{2}$-dca. These weak interactions generated 1D chains as shown in Figure 2(b). These 1D chains are linked by alternative $\mu_{1,5^{-}}$and $\mu_{1,3}$-dca bridges, which are less common for the dca ligand [88-95]. The weak copper (II) coordination leads to a pseudo-Jahn-Teller elongated octahedral geometry.

Adjacent coordination chains are extended into 2D hydrogen-bonded layers by the $\mathrm{O} 1-\mathrm{H} 1 \cdots \mathrm{N} 6 b$ hydrogen-bonding interaction between the hydroxyl groups and the uncoordinated nitrile ends of the dca ligands $(\mathrm{O} 1 \cdots \mathrm{N} 6 b=2.661(4) \AA$; $\mathrm{O} 1-\mathrm{H} 1 \mathrm{O} \cdots \mathrm{N} 6 b=172.5^{\circ}$ ), as shown in Figure 2(c).

Compound 3 crystallizes in monoclinic space group $P 2_{1} / c$ with the asymmetric unit consisting of half formula unit. The manganese ion is coordinated to one chelating hepH ligand, coordinating via the pyridyl nitrogen atom donor 
TABLE 2: Selected bond distances $(\AA)$ and angles (deg) for 1-3.

\begin{tabular}{|c|c|c|c|}
\hline \multicolumn{4}{|c|}{1} \\
\hline $\mathrm{Co}(1)-\mathrm{N}(1)$ & $2.0767(18)$ & $\mathrm{Co}(1)-\mathrm{O}(1)$ & $2.1653(15)$ \\
\hline $\mathrm{Co}(1)-\mathrm{N}(4)$ & $2.1136(16)$ & $\mathrm{O}(1)-\mathrm{H}(1 \mathrm{O}) \cdots \mathrm{N}(3 b)$ & $2.728(2)$ \\
\hline $\mathrm{N}(1)-\mathrm{Co}(1)-\mathrm{N}(1 a)$ & $95.73(10)$ & $\mathrm{N}(4)-\mathrm{Co}(1)-\mathrm{O}(1)$ & $75.41(6)$ \\
\hline $\mathrm{N}(1)-\mathrm{Co}(1)-\mathrm{N}(4)$ & $95.51(7)$ & $\mathrm{N}(1)-\mathrm{Co}(1)-\mathrm{O}(1 a)$ & $86.87(7)$ \\
\hline $\mathrm{N}(1)-\mathrm{Co}(1)-\mathrm{N}(4 a)$ & $96.88(7)$ & $\mathrm{N}(4)-\mathrm{Co}(1)-\mathrm{O}(1 a)$ & $91.63(6)$ \\
\hline $\mathrm{N}(4)-\mathrm{Co}(1)-\mathrm{N}(4 a)$ & $161.49(10)$ & $\mathrm{O}(1)-\mathrm{Co}(1)-\mathrm{O}(1 a)$ & $91.94(8)$ \\
\hline $\mathrm{N}(1)-\mathrm{Co}(1)-\mathrm{O}(1)$ & $170.81(6)$ & $\mathrm{O}(1)-\mathrm{H}(1 \mathrm{O}) \cdots \mathrm{N}(3 b)$ & 169.0 \\
\hline \multicolumn{4}{|c|}{2} \\
\hline $\mathrm{Cu}(1)-\mathrm{N}(4)$ & $1.965(3)$ & $\mathrm{Cu}(1)-\mathrm{N}(7)$ & $1.988(2)$ \\
\hline $\mathrm{Cu}(1)-\mathrm{N}(1)$ & $1.968(3)$ & $\mathrm{Cu}(1)-\mathrm{N}(3 a)$ & $2.323(3)$ \\
\hline $\mathrm{Cu}(1)-\mathrm{O}(1)$ & $1.985(2)$ & $\mathrm{O}(1) \cdots \mathrm{N}(6 \mathrm{~b})$ & $2.661(4)$ \\
\hline $\mathrm{N}(4)-\mathrm{Cu}(1)-\mathrm{N}(1)$ & $94.42(13)$ & $\mathrm{O}(1)-\mathrm{Cu}(1)-\mathrm{N}(7)$ & $80.68(10)$ \\
\hline $\mathrm{N}(4)-\mathrm{Cu}(1)-\mathrm{O}(1)$ & 89.38 (11) & $\mathrm{N}(4)-\mathrm{Cu}(1)-\mathrm{N}(3 a)$ & $99.62(12)$ \\
\hline $\mathrm{N}(1)-\mathrm{Cu}(1)-\mathrm{O}(1)$ & $176.08(10)$ & $\mathrm{N}(1)-\mathrm{Cu}(1)-\mathrm{N}(3 a)$ & $90.43(12)$ \\
\hline $\mathrm{N}(4)-\mathrm{Cu}(1)-\mathrm{N}(7)$ & $161.11(11)$ & $\mathrm{O}(1)-\mathrm{Cu}(1)-\mathrm{N}(3 a)$ & $89.90(11)$ \\
\hline $\mathrm{N}(1)-\mathrm{Cu}(1)-\mathrm{N}(7)$ & $95.41(11)$ & $\mathrm{N}(7)-\mathrm{Cu}(1)-\mathrm{N}(3 a)$ & $96.41(11)$ \\
\hline $\mathrm{O}(1)-\mathrm{H}(1 \mathrm{O}) \cdots \mathrm{N}(6 b)$ & 172.5 & & \\
\hline \multicolumn{4}{|c|}{3} \\
\hline $\mathrm{Mn}(1)-\mathrm{N}(3 a)$ & $2.175(4)$ & $\mathrm{Mn}(1)-\mathrm{N}(6 b)$ & $2.227(4)$ \\
\hline $\mathrm{Mn}(1)-\mathrm{O}(1)$ & $2.187(3)$ & $\mathrm{Mn}(1)-\mathrm{N}(4)$ & $2.238(4)$ \\
\hline $\operatorname{Mn}(1)-N(1)$ & $2.224(4)$ & $\operatorname{Mn}(1)-N(7)$ & $2.290(3)$ \\
\hline $\mathrm{O}(1) \cdots \mathrm{N}(5 d)$ & $2.859(4)$ & & \\
\hline $\mathrm{N}(3 a)-\mathrm{Mn}(1)-\mathrm{O}(1)$ & $174.77(14)$ & $\mathrm{N}(1)-\mathrm{Mn}(1)-\mathrm{N}(4)$ & $174.38(14)$ \\
\hline $\mathrm{N}(3 a)-\mathrm{Mn}(1)-\mathrm{N}(1)$ & $86.76(15)$ & $\mathrm{N}(6 b)-\mathrm{Mn}(1)-\mathrm{N}(4)$ & $87.05(14)$ \\
\hline $\mathrm{O}(1)-\mathrm{Mn}(1)-\mathrm{N}(1)$ & $88.34(13)$ & $\mathrm{N}(3 a)-\mathrm{Mn}(1)-\mathrm{N}(7)$ & $99.25(13)$ \\
\hline $\mathrm{N}(3 a)-\mathrm{Mn}(1)-\mathrm{N}(6 b)$ & $96.57(14)$ & $\mathrm{O}(1)-\mathrm{Mn}(1)-\mathrm{N}(7)$ & 82.67 (11) \\
\hline $\mathrm{O}(1)-\mathrm{Mn}(1)-\mathrm{N}(6 b)$ & $82.21(12)$ & $\mathrm{N}(1)-\mathrm{Mn}(1)-\mathrm{N}(7)$ & $91.21(13)$ \\
\hline $\mathrm{N}(1)-\mathrm{Mn}(1)-\mathrm{N}(6 b)$ & $96.92(14)$ & $\mathrm{N}(6 b)-\mathrm{Mn}(1)-\mathrm{N}(7)$ & $162.59(13)$ \\
\hline $\mathrm{N}(3 a)-\mathrm{Mn}(1)-\mathrm{N}(4)$ & $88.84(15)$ & $\mathrm{N}(4)-\mathrm{Mn}(1)-\mathrm{N}(7)$ & 86.05 (13) \\
\hline $\mathrm{O}(1)-\mathrm{Mn}(1)-\mathrm{N}(4)$ & $96.15(13)$ & $\mathrm{O}(1)-\mathrm{H}(1 \mathrm{O}) \cdots \mathrm{N}(5 d)$ & 165.2 \\
\hline
\end{tabular}

Symmetry codes: $(a)-x, y,-z+3 / 2 ;(b) x-1 / 2, y-1 / 2, z$ for $1 ;(a)-x+1,-y+2,-z+2 ;(b)-x+1,-y+3,-z+1$ for 2 . (a) $-x, y+1 / 2,-z+1 / 2 ;(b)$ $-x+1,-y-1,-z+1 ;(d) x,-y-3 / 2, z-1 / 2$ for 3 .

$(\mathrm{Mn}-\mathrm{N}=2.291(3) \AA)$ and hydroxyl oxygen atom $(\mathrm{Mn}-\mathrm{O}=$ $2.188(3) \AA$ ) and four nitrile nitrogen atoms from four $\mu_{1,5^{-}}$ dca anions $(\mathrm{Mn}-\mathrm{N}=2.175(4)-2.271(4) \AA)$, featuring a distorted $\mathrm{MnN}_{5} \mathrm{O}$ octahedron environment. The surrounding of manganese ion is shown in Figure 3(a). Each manganese ion is connected to another three manganese ions by means of two single ( $\mathrm{Mn} \cdots \mathrm{Mn}=8.192(1) \AA)$ and one double dca bridges $(\mathrm{Mn} \cdots \mathrm{Mn}=7.467(1) \AA)$, in an end-to-end $\left(\mu_{1,5}\right)$ coordination mode, leading to $2 \mathrm{D}(6,3)$ coordination layers (Figure 3(b)), which have been found in dca chemistry [30]. As expected, the dca anions do not coordinate linearly to the metal centers with C-N-Mn angles of $153.4(1)^{\circ}-169.7(1)^{\circ}$. As a result, the topology of the coordination network is that of a herringbone-waved grid since the rings have a slight chair conformation. The bidentate hepH ligands are located on both sides of each layer.
The 2D coordination layers are cross-linked by strong $\mathrm{O}-\mathrm{H} \cdot \cdots \mathrm{N}$ hydrogen-bonding interactions between hydroxyl group and amido nitrogen atoms of dca anions (O1 $\cdots \mathrm{N} 5 d=$ $\left.2.859(4) \AA ; \quad \mathrm{O} 1-\mathrm{H} 1 \mathrm{O} \cdots \mathrm{N} 5 d=165.2^{\circ}\right)$. These hydrogenbonding interactions extend these $2 \mathrm{D}$ layers into a $3 \mathrm{D}$ supramolecular architecture, which is further consolidated by the nonclassical $\mathrm{C}-\mathrm{H} \cdots \mathrm{N}$ hydrogen-bonding interaction, as shown in Figure 3(c).

3.3. Magnetic Properties. The magnetic properties of $\mathbf{3}$ are shown in Figure 4 as $\chi_{M}$ (inset) and $\chi_{M} T$ versus $T$ plots ( $\chi_{M}$ is the molar magnetic susceptibility for one $\mathrm{Mn}^{\mathrm{II}}$ ion). Taking into consideration the two-dimensional structure, magnetic data are taken for one manganese ion. The value of $\chi_{M} T$ product at $300 \mathrm{~K}$ is $4.19 \mathrm{~cm}^{3} \mathrm{~mol}^{-1} \mathrm{~K}$, which is the typical value for one isolated $\mathrm{Mn}(\mathrm{II})$ ion $(g=2.0)$. This 


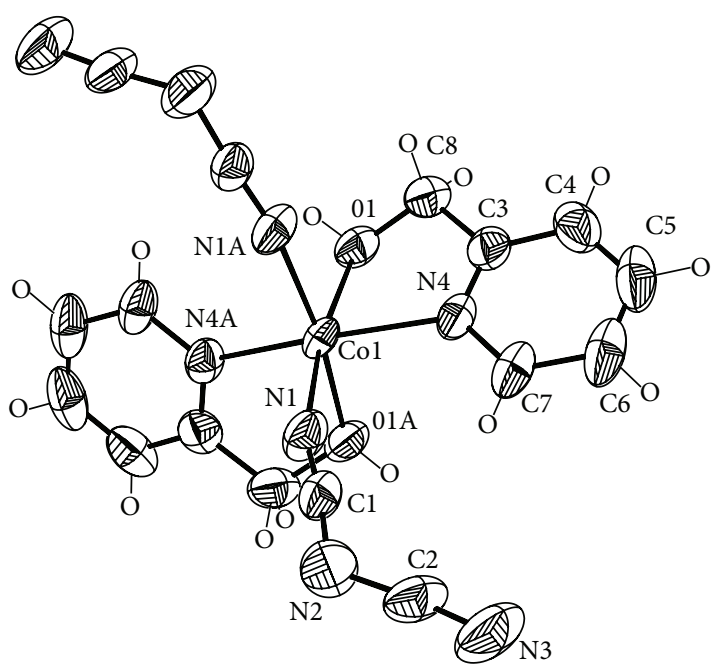

(a)

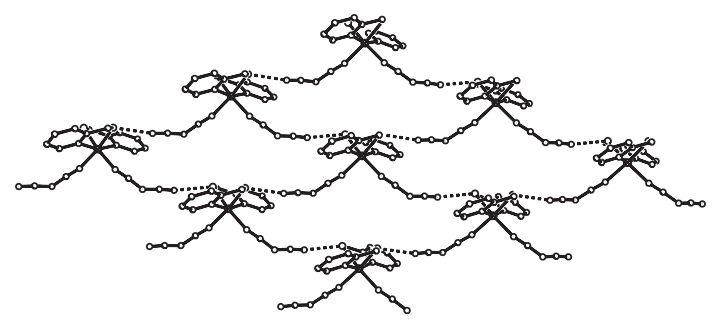

(b)

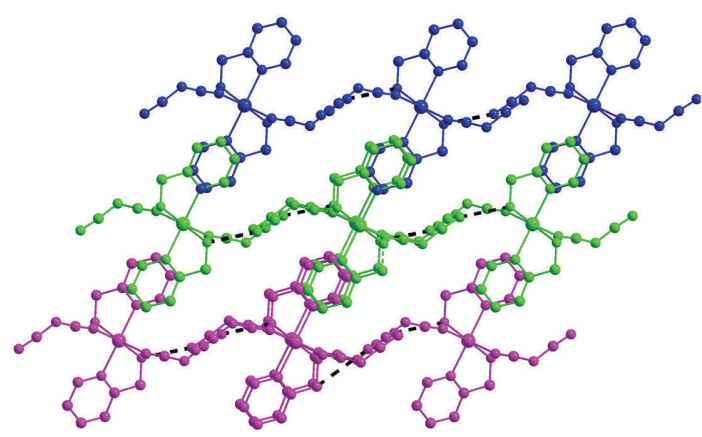

(c)

FIGURE 1: Coordination environments of the metal ions in $\mathbf{1}$ (a) and the hydrogen-bonded 2D layer (b). 3D molecular architecture with interbilayer $\pi-\pi$ interaction (c).

value remains unchanged up to $50 \mathrm{~K}$, and then decreases rapidly from $3.98 \mathrm{~cm}^{3} \mathrm{~mol}^{-1} \mathrm{~K}$ at ca. $50 \mathrm{~K}$ to $1.63 \mathrm{~cm}^{3} \mathrm{~mol}^{-1} \mathrm{~K}$ at $2.0 \mathrm{~K}$. This feature is indicative of weak antiferromagnetic coupling interaction among the $\mathrm{Mn}(\mathrm{II})$ ions. Because of the long $\mathrm{Mn} \cdots$ Mn separation of $8.192(1) \AA$ by single $\mu$-1,5-dca bridge in 3 , a simplified dinuclear $\mathrm{Mn}$ (II) model was used to analyze the magnetic exchange interaction via the two single and one double $\mu$-1,5-dca bridges $\left(\widehat{H}=-J S_{\mathrm{Mn}(1)} \cdot S_{\mathrm{Mn}(2)}\right)[96]$, similar to the reported method in [97]. The best-fit parameters are obtained to be $g=1.99, J=-0.011 \mathrm{~cm}^{-1}$, and $R=$ $1 \times 10^{-5}$. $J$ is the exchange interaction through double $\mu_{1,5}$-dca

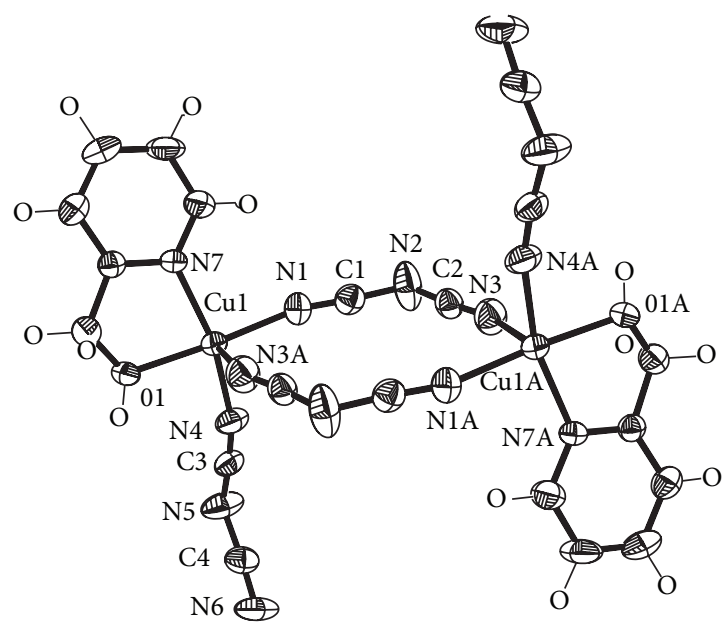

(a)

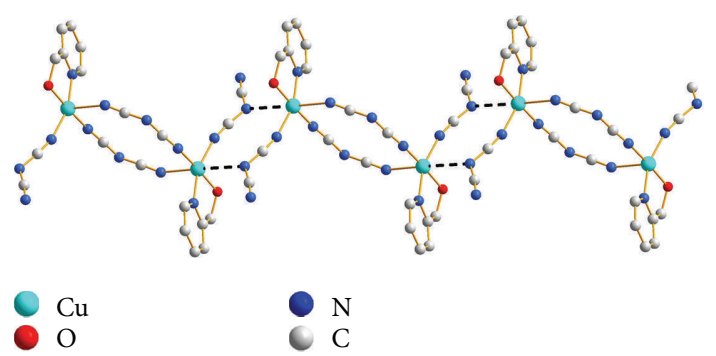

(b)

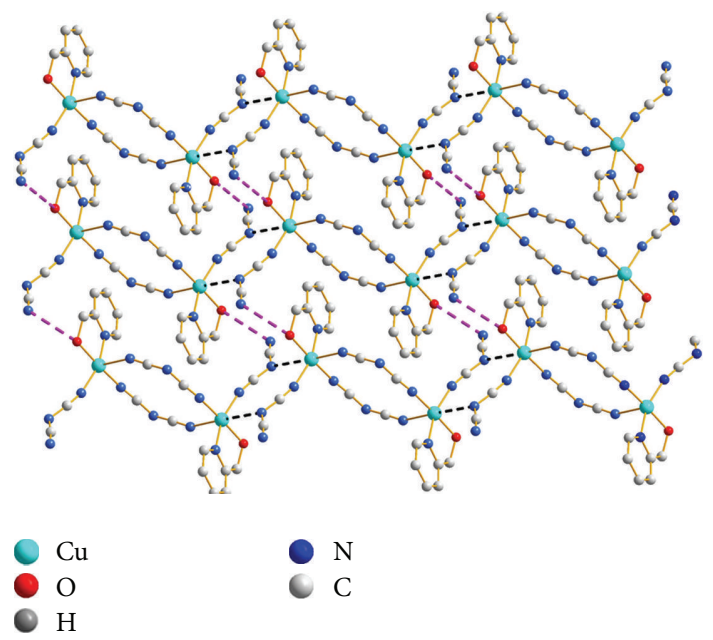

(c)

FIGURE 2: Coordination environments of the metal ions in 2 (a) and the $1 \mathrm{D}$ chain extended by $\mathrm{Cu}-\mathrm{N}$ weak interaction (b). $2 \mathrm{D}$ layer built by $\mathrm{N} \cdots \mathrm{H}-\mathrm{O}$ hydrogen bond (c).

bridges, $g$ is the Landé factor, and $R$ is the agreement factor for defined as $R=\left[\sum\left(\chi_{\text {obs }}-\chi_{\text {calc }}\right)^{2} / \sum \chi_{\text {obs }}{ }^{2}\right]^{1 / 2}$. This fitting result is in accordance with the very weak antiferromagnetic coupling existing in the reported $\mathrm{Mn}(\mathrm{II})-\mu_{1,5}$-dca-coligand systems [97] 


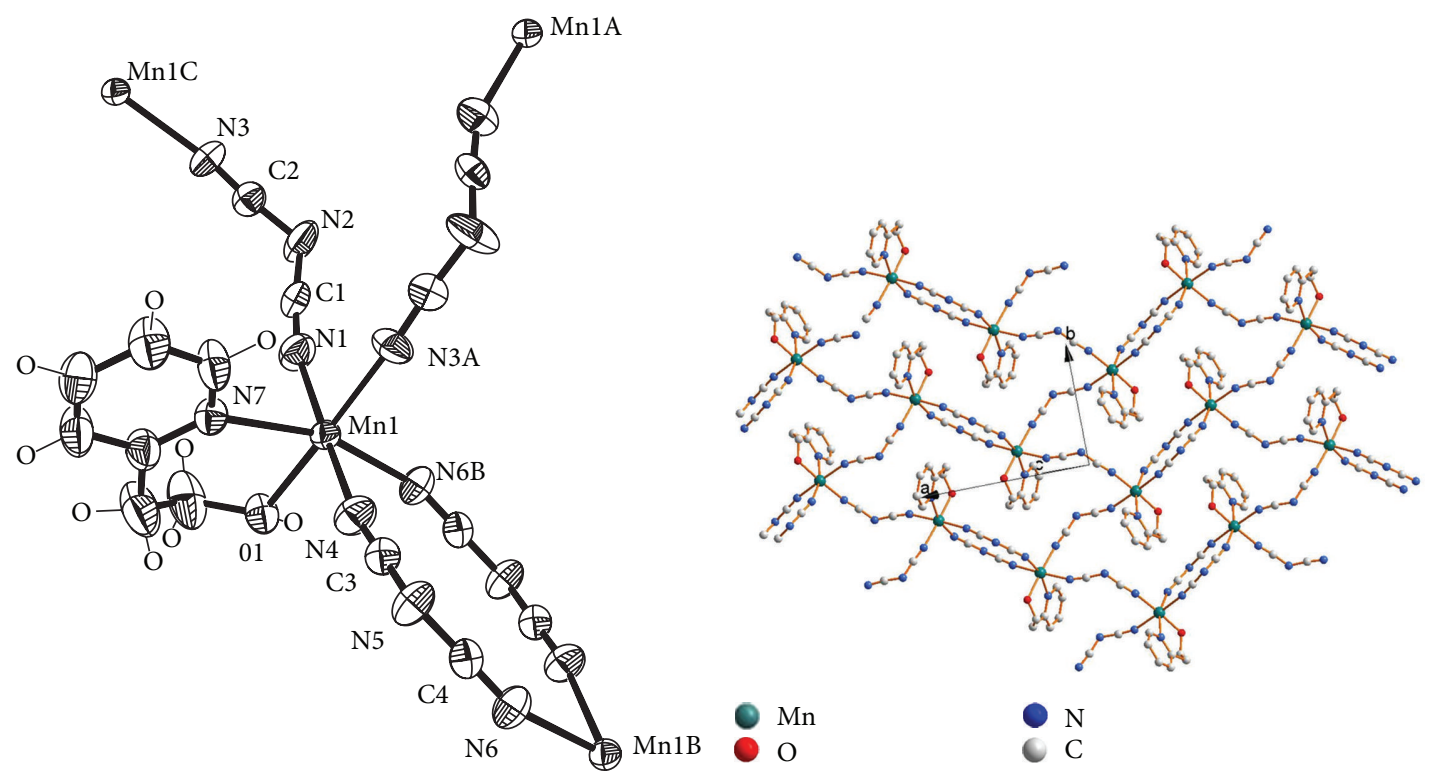

(a)

(b)

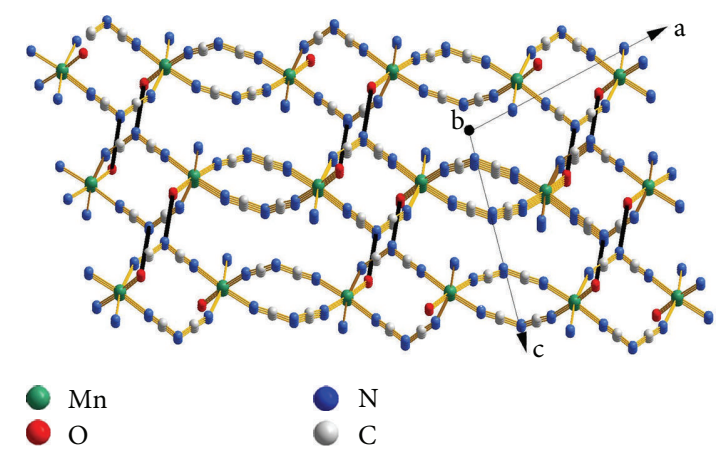

(c)

FIgURE 3: Coordination environments of the metal ions in 3 (a) and 2D layer (b). Hydrogen-bonded 3D network (c) (the uncoordinated atoms are deleted for clarity).

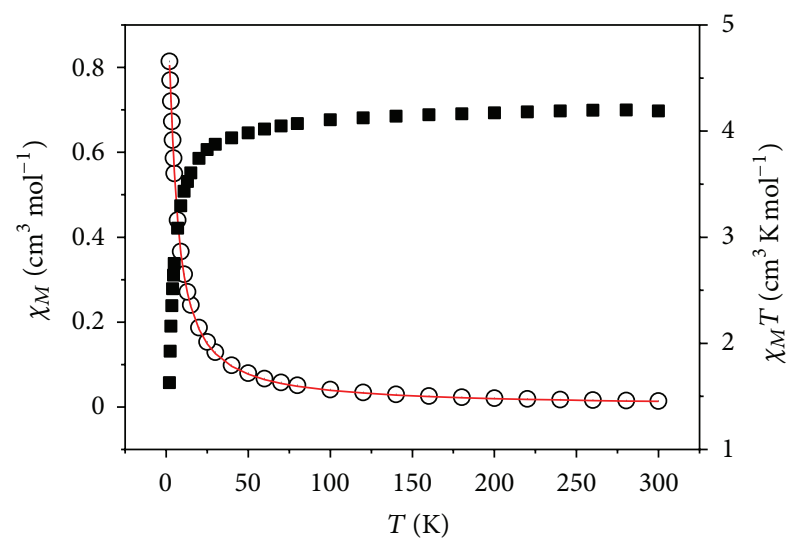

Figure 4: Plot of the $\chi_{M} T$ versus $T$. Solid lines represent the best fit with the parameters given in the text for 3 .

\section{Conclusion}

In this study, we have demonstrated the construction of ternary M(II)-dca-2-hydroxypyridine supramolecular architectures from low to high dimensionality via both metal coordination and hydrogen-bonding interactions. The dca ligand displays quite different coordination modes of monodentate in $\mathbf{1}$, double-bridge in $\mathbf{2}$, and single- and double-bridge fashion in $\mathbf{3}$. We are extending this strategy to construct new supramolecular architectures by using other functional coligands.

\section{References}

[1] B. F. Hoskins and R. Robson, "Design and construction of a new class of scaffolding-like materials comprising infinite polymeric frameworks of $3 \mathrm{D}$-linked molecular rods. A reappraisal of the zinc cyanide and cadmium cyanide structures and the synthesis and structure of the diamond-related frameworks [N(CH3)4][CuIZnII(CN)4] and CuI $\left[4,4^{\prime}, 4^{\prime \prime}, 4^{\prime \prime \prime}\right.$ tetracyanotetraphenylmethane]BF4.xC6H5NO2," Journal of the American Chemical Society, vol. 112, pp. 1545-1554, 1990.

[2] K. R. Seddon and M. Zaworotko, Eds., Crystal Engineering: The Design and Application of Functional Solids, Kluwer Academic, Dodrecht, The Netherlands, 1996. 
[3] G. R. Desiraju, "Supramolecular synthons in crystal engineering-a new organic synthesis," Angewandte Chemie International Edition, vol. 34, no. 21, pp. 2311-2327, 1995.

[4] C. B. Aakeröy and A. M. Beatty, "Review: crystal engineering of hydrogen-bonded assemblies-a progress report," Australian Journal of Chemistry, vol. 54, no. 7, pp. 409-421, 2001.

[5] K. T. Holman, A. M. Pivovar, J. A. Swift, and M. D. Ward, "Metric engineering of soft molecular host frameworks," Accounts of Chemical Research, vol. 34, no. 2, pp. 107-118, 2001.

[6] A. D. Burrows, "Crystal engineering using multiple hydrogen bonds," Structure and Bonding, vol. 108, pp. 55-96, 2004.

[7] D. Braga, L. Maini, M. Polito, and F. Grepioni, "Hydrogen bonding interactions between ions: a powerful tool in molecular crystal engineering," Structure and Bonding, vol. 111, pp. 1-32, 2004.

[8] A. J. Blake, N. R. Champness, P. Hubberstey, W. S. Li, M. A. Withersby, and M. Schröder, "Inorganic crystal engineering using self-assembly of tailored building-blocks," Coordination Chemistry Reviews, vol. 183, no. 1, pp. 117-138, 1999.

[9] B. Moulton and M. J. Zaworotko, "From molecules to crystal engineering: supramolecular isomerism and polymorphism in network solids," Chemical Reviews, vol. 101, no. 6, pp. 1629-1658, 2001.

[10] L. Carlucci, G. Ciani, and D. M. Proserpio, "Polycatenation, polythreading and polyknotting in coordination network chemistry," Coordination Chemistry Reviews, vol. 246, no. 1-2, pp. 247-289, 2003.

[11] C. Janiak, "Engineering coordination polymers towards applications," Dalton Transactions, no. 14, pp. 2781-2804, 2003.

[12] R. Robson, "A net-based approach to coordination polymers," Journal of the Chemical Society, Dalton Transactions, vol. 2000, no. 21, pp. 3735-3744, 2000.

[13] S. Kitagawa and S. Masaoka, "Metal complexes of hexaazatriphenylene (hat) and its derivatives-from oligonuclear complexes to coordination polymers," Coordination Chemistry Reviews, vol. 246, pp. 73-88, 2003.

[14] K. Biradha, "Crystal engineering: from weak hydrogen bonds to co-ordination bonds," CrystEngComm, vol. 5, pp. 374-384, 2003.

[15] A. M. Beatty, "Open-framework coordination complexes from hydrogen-bonded networks: toward host/guest complexes," Coordination Chemistry Reviews, vol. 246, pp. 131-143, 2003.

[16] C. N. R. Rao, S. Natarajan, and R. Vaidhyanathan, "Metal carboxylates with open architectures," Angewandte Chemie International Edition, vol. 43, no. 12, pp. 1466-1496, 2004.

[17] P. J. Hagrman, D. Hagrman, and J. Zubieta, "Organic-inorganic hybrid materials: from "Simple" coordination polymers to organodiamine-templated molybdenum oxides," Angewandte Chemie International Edition, vol. 38, pp. 2638-2684, 1999.

[18] O. Kahn, "Chemistry and physics of supramolecular magnetic materials," Accounts of Chemical Research, vol. 33, no. 10, pp. 647-657, 2000.

[19] O. R. Evans and W. Lin, "Crystal engineering of NLO materials based on metal-organic coordination networks," Accounts of Chemical Research, vol. 35, pp. 511-522, 2002.

[20] O. M. Yaghi, M. O’Keeffe, N. W. Ockwig, H. K. Chae, M. Eddaoudi, and J. Kim, "Reticular synthesis and the design of new materials," Nature, vol. 423, no. 6941, pp. 705-714, 2003.

[21] B. Kesanli and W. Lin, "Chiral porous coordination networks: rational design and applications in enantioselective processes," Coordination Chemistry Reviews, vol. 246, no. 1-2, pp. 305-326, 2003.
[22] S. Kitagawa, R. Kitaura, and S. I. Noro, "Functional porous coordination polymers," Angewandte Chemie International Edition, vol. 43, no. 18, pp. 2334-2375, 2004.

[23] S. R. Batten and R. Robson, "Interpenetrating nets: ordered, periodic entanglement," Angewandte Chemie International Edition, vol. 37, pp. 1460-1494, 1998.

[24] S. Leininger, B. Olenyuk, and P. J. Stang, "Self-assembly of discrete cyclic nanostructures mediated by transition metals," Chemical Reviews, vol. 100, no. 3, pp. 853-908, 2000.

[25] G. F. Swiegers and T. J. Malefetse, "New self-assembled structural motifs in coordination chemistry," Chemical Reviews, vol. 100, no. 9, pp. 3483-3537, 2000.

[26] B. J. Holliday and C. A. Mirkin, "Strategies for the construction of supramolecular compounds through coordination chemistry," Angewandte Chemie International Edition, vol. 40, pp. 2022-2043, 2001.

[27] M. Eddaoudi, D. B. Moler, H. Li et al., "Modular chemistry: secondary building units as a basis for the design of highly porous and robust metal-organic carboxylate frameworks," Accounts of Chemical Research, vol. 34, no. 4, pp. 319-330, 2001.

[28] D. L. Caulder and K. N. Raymond, "Supermolecules by design," Accounts of Chemical Research, vol. 32, no. 11, pp. 975-982, 1999.

[29] Y. Rodíguez-Martín, M. Hernández-Molina, F. S. Delgado et al., "Structural versatility of the malonate ligand as a tool for crystal engineering in the design of molecular magnets," CrystEngComm, vol. 4, pp. 522-535, 2002.

[30] S. R. Batten and K. S. Murray, "Structure and magnetism of coordination polymers containing dicyanamide and tricyanomethanide," Coordination Chemistry Reviews, vol. 246, no. 1-2, pp. 103-130, 2003.

[31] S. R. Batten, P. Jensen, C. J. Kepert et al., "Syntheses, structures and magnetism of $\alpha-\mathrm{Mn}(\mathrm{dca})_{2},\left[\mathrm{Mn}(\mathrm{dca})_{2}\left(\mathrm{H}_{2} \mathrm{O}\right)_{2}\right] \cdot \mathrm{H}_{2} \mathrm{O},[\mathrm{Mn}$ $\left.(\mathrm{dca})_{2}\left(\mathrm{C}_{2} \mathrm{H}_{5} \mathrm{OH}\right)_{2}\right] \cdot\left(\mathrm{CH}_{3}\right)_{2} \mathrm{CO},\left[\mathrm{Fe}(\mathrm{dca})_{2}\left(\mathrm{CH}_{3} \mathrm{OH}\right)_{2}\right]$," Journal of the Chemical Society, no. 17, pp. 2987-2997, 1999.

[32] I. Dasna, S. Golhen, L. Ouahab, O. Peña, J. Guillevic, and M. Fettouhi, "1-D mixed stack of coordinated and uncoordinated radicals in $\mathrm{Mn}^{\mathrm{II}}(\mathrm{NITpPy})_{4}\left[\mathrm{~N}(\mathrm{CN})_{2}\right]_{2}(\mathrm{NITpPy}=$ nitronyl nitroxide radical)," Journal of the Chemical Society, Dalton Transactions, no. 2, pp. 129-132, 2000.

[33] G. A. van Albada, M. E. Quiroz-Castro, I. Mutikainen, U. Turpeinen, and J. Reedijk, "The first structural evidence of a polymeric $\mathrm{Cu}(\mathrm{II})$ compound with a bridging dicyanamide anion: X-ray structure, spectroscopy and magnetism of catena-[polybis(2-aminopyrimidine)copper(II)-bis( $\mu$-dicyanamido)]," Inorganica Chimica Acta, vol. 298, no. 2, pp. 221-225, 2000.

[34] A. Escuer, F. A. Mautner, N. Sanz, and R. Vicente, "Two new one-dimensional compounds with end-to-end dicyanamide as a bridging ligand: syntheses and structural characterization of trans-[Mn(4-bzpy $\left.)_{2}\left(\mathrm{~N}(\mathrm{CN})_{2}\right)_{2}\right]_{n}$ and cis- $[\mathrm{Mn}(\mathrm{Bpy})$ $\left.\left(\mathrm{N}(\mathrm{CN})_{2}\right)_{2}\right]_{n}, \quad\left(4\right.$-bzpy $=4$-benzoylpyridine; bp $=2,2^{\prime}$ - bipyridyl)," Inorganic Chemistry, vol. 39, no. 8, pp. 1668-1673, 2000.

[35] J. H. Luo, M. C. Hong, R. Cao et al., "Syntheses and crystal structures of cadmium(II) coordination polymers with end-toend dicyanamide bridges," Polyhedron, vol. 21, no. 8, pp. 893898, 2002.

[36] S. Martín, M. G. Barandika, J. I. R. de Larramendi et al., "Structural analysis and magnetic properties of the $1 \mathrm{D}$ and $3 \mathrm{D}$ compounds $\left[\mathrm{M}_{n}(\mathrm{dca})_{2 n}\right.$ bipym $](M=M n, \mathrm{Cu}$; dca = dicyanamide; bipym = bipyrimidine; $n=1,2)$," Inorganic Chemistry, vol. 40, no. 15, pp. 3687-3692, 2001. 
[37] I. Dasna, S. Golhen, L. Ouahab, N. Daro, and J. P. Sutter, "Synthesis, X-ray crystal structures and magnetic properties of CuII and MnII complexes containing imino nitroxide radicals and a dicyanamide anion," New Journal of Chemistry, vol. 25, no. 12, pp. 1572-1576, 2001.

[38] B. Vangdal, J. Carranza, F. Lloret, M. Julve, and J. Sletten, "Syntheses, crystal structures and magnetic properties of copper(II) dicyanamide complexes; dinuclear, chain and ladder compounds," Journal of the Chemical Society, Dalton Transactions, no. 4, pp. 566-574, 2002.

[39] J. Carranza, C. Brennan, J. Sletten, F. Lloret, and M. Julve, "Three one-dimensional systems with end-to-end dicyanamide bridges between copper(II) centres: structural and magnetic properties," Journal of the Chemical Society, Dalton Transactions, no. 16, pp. 3164-3170, 2002.

[40] S. Dalai, P. S. Mukherjee, E. Zangrando, and N. Ray Chaudhuri, "Synthesis, crystal structure and magnetic properties of two new dicyanamide bridged 2D and 1D complexes of Mn(II)," New Journal of Chemistry, vol. 26, no. 9, pp. 1185-1189, 2002.

[41] M. Du, X. J. Zhao, S. R. Batten, and J. Ribas, "From 1-D coordination polymers to 3-D hydrogen-bonding networks: crystal engineering and magnetism of $\mathrm{Cu}^{\mathrm{II}}-\mathrm{dca}-$ cyanopyridine supramolecular systems (dca = dicyanamide, $\left.\mathrm{N}(\mathrm{CN})_{2}{ }^{-}\right)$," Crystal Growth and Design, vol. 5, pp. 901-909, 2005.

[42] M. Du, X.G. Wang, Z. H. Zhang, L. F. Tang, and X. J. Zhang, "Solvent-directed layered Co(II) coordination polymers with unusual solid-state properties: from a nanoporous framework to the dense polythreading 3-D aggregation ," CrystEngComm, vol. 8, pp. 788-793, 2006.

[43] C. R. Kmety, J. L. Manson, Q. Z. Huang et al., "Magnetic Phase Transitions in $\mathrm{Mn}^{\mathrm{II}}\left[\mathrm{N}(\mathrm{CN})_{2}\right]_{2}$," Molecular Crystals and Liquid Crystals Science and Technology A, vol. 334, pp. 631-640, 1999.

[44] J. L. Manson, C. R. Kmety, Q. Z. Huang et al., "Structure and magnetic ordering of $\mathrm{Mn}^{\mathrm{II}}\left[\mathrm{N}(\mathrm{CN})_{2}\right]_{2}(M=\mathrm{Co}, \mathrm{Ni})$," Chemistry of Materials, vol. 10, no. 9, pp. 2552-2560, 1998.

[45] S. R. Batten, P. Jensen, B. Moubaraki, K. S. Murray, and R. Robson, "Structure and molecular magnetism of the rutile-related compounds $\mathrm{M}(\mathrm{dca})_{2}, \mathrm{M}=\mathrm{Co}^{\mathrm{II}}, \mathrm{Ni}^{\mathrm{II}}, \mathrm{Cu}^{\mathrm{II}}$, dca = dicyanamide, $\mathrm{N}(\mathrm{CN})_{2}{ }^{-}$," Chemical Communications, no. 3, pp. 439-440, 1998.

[46] M. Kurmoo and C. J. Kepert, "Hard magnets based on transition metal complexes with the dicyanamide anion, $\left\{\mathrm{N}(\mathrm{CN})_{2}\right\}^{-}$," New Journal of Chemistry, vol. 22, no. 12, pp. 1515-1524, 1998.

[47] J. L. Manson, C. R. Kmety, F. Palacio, A. J. Epstein, and J. S. Miller, "Low-field remanent magnetization in the weak ferromagnet $\mathrm{Mn}\left[\mathrm{N}(\mathrm{CN})_{2}\right]_{2}$. Evidence for spin-flop behavior," Chemistry of Materials, vol. 13, no. 3, pp. 1068-1073, 2001.

[48] C. R. Kmety, Q. Huang, J. W. Lynn et al., "Noncollinear antiferromagnetic structure of the molecule-based magnet $\mathrm{Mn}\left[\mathrm{N}(\mathrm{CN})_{2}\right]_{2}$," Physical Review B, vol. 62, no. 9, pp. 5576-5588, 2000.

[49] C. X. Zhang, Z. Q. Liu, D. Z. Liao, and S. P. Yan, "A novel ferromagnetic coupling one-dimensional complex $\{\mathrm{Cu}(\mathrm{II})$ $\left.(\mathrm{NIT} 3 \mathrm{Py})_{2}\left[\mathrm{~N}(\mathrm{CN})_{2}\right]_{2}\left(\mathrm{H}_{2} \mathrm{O}\right)_{2}\right\}$," Inorganica Chimica Acta, vol. 357, no. 2, pp. 376-380, 2004.

[50] D. Ghoshal, A. K. Ghosh, J. Ribas et al., "Synthesis, crystal structure, and magnetic behavior of two dicyanamido-bridged complexes of manganese(II): effect of weak interaction in carving regular geometry," Crystal Growth and Design, vol. 5, no. 3, pp. 941-947, 2005.

[51] B. W. Sun, S. Gao, B. Q. Ma, and Z. M. Wang, "Syntheses, structures and magnetic properties of 1-D coordination polymers containing both dicyanamide and 2-pyrrolidone," Inorganic Chemistry Communications, vol. 4, no. 2, pp. 72-75, 2001.

[52] J. L. Manson, A. M. Arif, C. D. Incarvito, L. M. Liable-Sands, A. L. Rheingold, and J. S. Miller, "Structures and magnetic properties of novel 1-D coordination polymers containing both dicyanamide and pyridine-type ligands," Journal of Solid State Chemistry, vol. 145, no. 2, pp. 369-378, 1999.

[53] W. Dong, M. Liang, Y. Q. Sun, and Z. Q. Liu, "Syntheses and structures of two 1-D complexes, $\left.\left[\mathrm{Co}(\mathrm{dmf})_{2} \mathrm{NCNCN}\right)_{2}\right]$ and $[\mathrm{Cu}$ (bipy) $(\mathrm{NCNCN})] \mathrm{ClO}_{4}$ with bridging dicyanamide ligands," Zeitschrift für Anorganische und Allgemeine Chemie, vol. 629, no. 14, pp. 2443-2445, 2003.

[54] A. Escuer, F. A. Mautner, N. Sanz, and R. Vicente, "Syntheses, structures and magnetic properties of the dicyanamide (dca) polynuclear compounds $\left[\mathrm{Mn}(\mathrm{ac})(\text { terpy })\left(\mu_{1,5} \text {-dca }\right)\right]_{n},\left[\mathrm{Mn}(\mathrm{pdz})_{2}\right.$ $\left.\left(\mu_{1,5}-\mathrm{dca}\right)_{2}\right]_{n}$ and $\left[\{\mathrm{Mn}(\mathrm{dca})(\text { terpy })(\mathrm{MeOH})\}_{2}(\mu\right.$-terephthalate)]," Inorganica Chimica Acta, vol. 340, pp. 163-169, 2002.

[55] A. Escuer, F. A. Mautner, N. Sanz, and R. Vicente, "Two new one-dimensional compounds with end-to-end dicyanamide as a bridging ligand: syntheses and structural characterization of trans-[Mn(4-bzpy $\left.)_{2}\left(\mathrm{~N}(\mathrm{CN})_{2}\right)_{2}\right]_{n}$ and cis-[Mn(Bpy) $\left.\left(\mathrm{N}(\mathrm{CN})_{2}\right)_{2}\right]_{n}, \quad\left(4\right.$-bzpy $=4$-benzoylpyridine; bpy $=2,2^{\prime}$ bipyridyl)," Inorganic Chemistry, vol. 39, pp. 1668-1673, 2000.

[56] S. Dalai, P. S. Mukherjee, E. Zangrando, and N. Ray Chaudhuri, "Synthesis, crystal structure and magnetic properties of two new dicyanamide bridged 2D and 1D complexes of $\mathrm{Mn}(\mathrm{II})$," New Journal of Chemistry, vol. 26, no. 9, pp. 1185-1189, 2002.

[57] A. J. Zhou, L. L. Zheng, and M. L. Tong, "Catena-Poly [[dimethanolcobalt(II)]-di- $\mu$-1, 5-dicyanamido]," Acta Crystallographica, vol. E60, pp. m1254-m1255, 2004.

[58] S. R. Batten, P. Jensen, C. J. Kepert et al., "Syntheses, structures and magnetism of $\alpha-\mathrm{Mn}(\mathrm{dca})_{2},\left[\mathrm{Mn}(\mathrm{dca})_{2}\left(\mathrm{H}_{2} \mathrm{O}\right)_{2}\right] \cdot \mathrm{H}_{2} \mathrm{O},[\mathrm{Mn}$ (dca $\left.)_{2}\left(\mathrm{C}_{2} \mathrm{H}_{5} \mathrm{OH}\right)_{2}\right] \cdot\left(\mathrm{CH}_{3}\right)_{2} \mathrm{CO},\left[\mathrm{Fe}(\mathrm{dca})_{2}\left(\mathrm{CH}_{3} \mathrm{OH}\right)_{2}\right]$," Journal of the Chemical Society, Dalton Transactions, no. 17, pp. 29872997, 1999.

[59] D. Armentano, G. de Munno, F. Guerra, J. Faus, F. Lloret, and M. Julve, "2,2'-Bipyrimidine- and 2,3-bis(2-pyridyl)pyrazinecontaining manganese(II) compounds: structural and magnetic properties," Dalton Transactions, no. 24, pp. 4626-4634, 2003.

[60] S. Konar, S. Dalai, P. S. Mukherjee, M. G. B. Drew, J. Ribas, and N. R. Chaudhuri, "Two new NiII complexes with $\mu_{1,5^{-}}$ dicyanamide as bridging ligand," Inorganica Chimica Acta, vol. 358, no. 4, pp. 957-963, 2005.

[61] J. L. Manson, J. A. Schlueter, and C. L. Nygren, "Mn(dca) $(\text { pym })_{2}$ and $\mathrm{Mn}(\mathrm{dca})_{2}(\mathrm{pym})\left(\mathrm{H}_{2} \mathrm{O}\right)\{\mathrm{dca}=$ dicyanamide; $\mathrm{pym}=$ pyrimidine $\}$ : new coordination polymers exhibiting 1- and 2-D topologies," Dalton Transactions, vol. 2007, no. 6, pp. 646-652, 2007.

[62] A. Q. Wu, F. K. Zheng, L. Z. Cai, G. C. Guo, and J. S. Huang, "Syntheses and crystal structures of two novel 1-D metal complexes with dicyanamide: $\left[\mathrm{Zn}(\text { pheen })(\mathrm{dca})_{2}\right]_{n}$ and $\left[\mathrm{Cu}(\text { quin })_{2}(\mathrm{dca})_{2}\right]_{n}$," Chinese Journal of Structural Chemistry, vol. 23, p. 1143, 2004.

[63] J. H. Luo, M. C. Hong, R. Cao et al., "Syntheses and crystal structures of cadmium(II) coordination polymers with end-toend dicyanamide bridges," Polyhedron, vol. 21, no. 8, pp. 893898, 2002.

[64] H. L. Sun, S. Gao, B. Q. Ma, G. Su, and S. R. Batten, "Structures and magnetism of a series $\mathrm{Mn}(\mathrm{II})$ coordination polymers containing pyrazine-dioxide derivatives and different anions," Crystal Growth and Design, vol. 5, no. 1, pp. 269-277, 2005. 
[65] J. L. Manson, J. Y. Gu, J. A. Schlueter, and H. H. Wang, "Structures and magnetic behavior of 1-, 2-, and 3D coordination polymers in the $\mathrm{Cu}(\mathrm{II})$-dicyanamide-pyrimidine family," Inorganic Chemistry, vol. 42, pp. 3950-3955, 2003.

[66] P. Jensen, S. R. Batten, B. Moubaraki, and K. S. Murray, "Syntheses, crystal structures, and magnetic properties of first row transition metal coordination polymers containing dicyanamide and 4,4'-bipyridine," Journal of the Chemical Society, Dalton Transactions, no. 19, pp. 3712-3722, 2002.

[67] S. Triki, F. Thetiot, J. R. Galán-Mascarós, and J. S. Pala, "New compounds with bridging dicyanamide and bis-chelating $2,2^{\prime}$ bipyrimidine ligands: syntheses, structural characterisation and magnetic properties of the two-dimensional materials $\left[\mathrm{Fe}_{2}(\mathrm{dca})_{4}(\mathrm{bpym})\right] \cdot \mathrm{H}_{2} \mathrm{O}$ and $\left[\mathrm{Fe}_{2}(\mathrm{dca})_{4}(\mathrm{bpym})\left(\mathrm{H}_{2} \mathrm{O}\right)_{2}\right]$," $\mathrm{New}$ Journal of Chemistry, vol. 25, pp. 954-958, 2001.

[68] M. L. Tong, Y. M. Wu, Y. X. Tong, X. M. Chen, H. C. Chang, and S. Kitagawa, "Rational design of a ferromagnetic trinuclear copper(II) complex with a novel in-situ synthesised metalloligand," European Journal of Inorganic Chemistry, vol. 2003, no. 13, pp. 2385-2388, 2003.

[69] L. L. Zheng, W. X. Zhang, L. J. Qin, J. D. Leng, J. X. Lu, and M. L. Tong, "Isolation of a pentadentate ligand and stepwise synthesis, structures, and magnetic properties of a new family of homoand heterotrinuclear complexes," Inorganic Chemistry, vol. 46, pp. 9548-9557, 2007.

[70] L. L. Zheng, H. X. Li, J. D. Leng, J. Wang, and M. L. Tong, “Two photoluminescent metal-organic frameworks constructed from $\mathrm{Cd}_{3}\left(\mu_{3}-\mathrm{OH}\right)$ cluster or $1 \mathrm{D} \mathrm{Zn}_{5}\left(\mu_{3}-\mathrm{OH}\right)_{2}(\mu-\mathrm{OH})_{2}$ chain units and in situ formed Bis(tetrazole)amine ligands," European Journal of Inorganic Chemistry, vol. 2008, no. 2, pp. 213-217, 2008.

[71] L. L. Zheng, J. D. Leng, W. T. Liu, W. X. Zhang, J. X. Lu, and M. L. Tong, " $\mathrm{Cu}^{2+}$-mediated nucleophilic addition of different nucleophiles to dicyanamide-synthesis, structures, and magnetic properties of a family of mononuclear, trinuclear, hexanuclear, and polymeric copper(II) complexes," European Journal of Inorganic Chemistry, vol. 2008, no. 29, pp. 4616-4624, 2008.

[72] L. L. Zheng, C. K. Tan, and M. L. Tong, "Synthesis and crystal structures of $\mathrm{Mn}(\mathrm{II}) / \mathrm{Co}(\mathrm{II})$ - dicyanamide-4-(1H-imidazol1-yl)aniline ternary complexs," Chinese Journal of Inorganic Chemistry, vol. 22, pp. 1426-1430, 2006.

[73] A. Igashira-Kamiyama, T. Kajiwara, T. Konno, and T. Ito, "Ferromagnetic coupling promoted by $\kappa 3 \mathrm{~N}: \kappa 2 \mathrm{~N}$ bridging system," Inorganic Chemistry, vol. 45, no. 16, pp. 6460-6466, 2006.

[74] I. Castro-Rodriguez, K. Olsen, P. Gantzel, and K. Meyer, "Uranium complexes supported by an aryloxide functionalised triazacyclononane macrocycle: synthesis and characterisation of a six-coordinate U(III) species and insights into its reactivity," Chemical communications, no. 23, pp. 2764-2765, 2002.

[75] L. Brammer, "Metals and hydrogen bonds," Dalton Transactions, no. 16, pp. 3145-3157, 2003.

[76] H. W. Roesky and M. Andruh, "The interplay of coordinative, hydrogen bonding and $\pi-\pi$ stacking interactions in sustaining supramolecular solid-state architectures.: a study case of bis(4pyridyl)- and bis(4-pyridyl- $N$-oxide) tectons," Coordination Chemistry Reviews, vol. 236, pp. 91-119, 2003.

[77] G. M. Sheldrick, SADABS 2.05, University Göttingen.

[78] SHELXTL 6.10, Bruker Analytical Instrumentation, Madison, Wis, USA, 2000.

[79] T. C. Stamatatos, K. A. Abboud, W. Wernsdorfer, and G. Christou, "High-nuclearity, high-symmetry, high-spin molecules: a mixed-valence $\mathrm{Mn}_{10}$ cage possessing rare $T$ symmetry and an $S=22$ ground State," Angewandte Chemie International Edition, vol. 45, no. 25, pp. 4134-4137, 2006.

[80] J. Yoo, A. Yamaguchi, M. Nakano et al., "Mixed-valence tetranuclear manganese single-molecule magnets," Inorganic Chemistry, vol. 40, no. 18, pp. 4604-4616, 2001.

[81] D. N. Hendrickson, G. Christou, H. Ishimoto et al., "Magnetization tunneling in single-molecule magnets," Polyhedron, vol. 20, no. 11-14, pp. 1479-1488, 2001.

[82] L. Lecren, O. Roubeau, C. Coulon et al., "Slow relaxation in a one-dimensional rational assembly of antiferromagnetically coupled $\left[\mathrm{Mn}_{4}\right]$ single-molecule magnets," Journal of the American Chemical Society, vol. 127, no. 49, pp. 17353-17363, 2005.

[83] H. Miyasaka, K. Nakata, L. Lecren et al., "Two-dimensional networks based on $\mathrm{Mn}_{4}$ complex linked by dicyanamide anion: from single-molecule magnet to classical magnet behavior," Journal of the American Chemical Society, vol. 128, no. 11, pp. 3770-3783, 2006.

[84] H. Miyasaka, K. Nakata, K. Sugiura, M. Yamashita, and R. Clérac, "A three-dimensional ferrimagnet composed of mxedvalence $\mathrm{Mn}_{4}$ clusters linked by an $\left\{\mathrm{Mn}\left[\mathrm{N}(\mathrm{CN})_{2}\right]_{6}\right\}^{4-}$ unit," Angewandte Chemie International Edition, vol. 43, no. 6, pp. 707-711, 2004.

[85] J. Yoo, W. Wernsdorfer, E. C. Yang, M. Nakano, A. L. Rheingold, and D. N. Hendrickson, "One-dimensional chain of tetranuclear manganese single-molecule magnets," Inorganic Chemistry, vol. 44, no. 10, pp. 3377-3379, 2005.

[86] H. K. Köhler, A. Kolbe, and G. Lux, "Metall-pseudohalogenide. 27. Zur struktur der dicyanamide zweiwertiger 3d-Metalle $\mathrm{M}\left(\mathrm{N}(\mathrm{CN})_{2}\right)_{2}$," Zeitschrift für Anorganische und Allgemeine Chemie, vol. 428, pp. 103-112, 1977.

[87] G. R. Desiraju and T. Steiner, The Weak Hydrogen Bond in Structural Chemistry and Biology, Oxford University Press, Oxford, UK, 1999.

[88] B. W. Sun, S. Gao, B. Q. Ma, D. Z. Niu, and Z. M. Wang, "Syntheses, structures and magnetic properties of three-dimensional co-ordination polymers constructed by dimer subunits ," Journal of the Chemical Society, Dalton Transactions, no. 22, pp. 4187-4191, 2000.

[89] Z. M. Wang, B. W. Sun, J. Luo et al., "Bimetallic sandwiches assembled with chelated $\mathrm{Cu} / \mathrm{Zn}$ cations and manganese dicyanamide polymeric ladders," Polyhedron, vol. 22, no. 3, pp. 433-439, 2003.

[90] B. W. Sun, S. Gao, B. Q. Ma, and Z. M. Wang, "Syntheses, structures and magnetic properties of 1-D coordination polymerscontaining both dicyanamide and 2-pyrrolidone," Inorganica Chimica Acta, vol. 4, pp. 72-75, 2001.

[91] Z. M. Wang, B. W. Sun, J. Luo et al., "Bimetallic sheet and 3D threefold interpenetrating diamond-like network constructed by chelate $\mathrm{Cu}$ cations and $\mathrm{Mn}$ dicyanamide polymeric chains. Synthesis, crystal structure, and magnetism of $[\mathrm{Cu}$ $\left.(\mathrm{L})_{2}\right]\left[\mathrm{Mn}(\mathrm{dca})_{4}\right](\mathrm{L}=$ ethylenediamine or 1,3-diaminopropane; $\mathrm{dca}=$ dicyanamide $\mathrm{N}(\mathrm{CN})_{2}{ }^{-}$)," Inorganica Chimica Acta, vol. 332, no. 1, pp. 127-134, 2002.

[92] W. F. Yeung, S. Gao, W. T. Wong, and T. C. Lau, "Antiferromagnetic ordering in a novel five-connected 3-D polymer $\mathrm{Cu}_{2}(2,5-$ $\mathrm{Me}_{2}$ pyz $)\left[\mathrm{N}(\mathrm{CN})_{2}\right]_{4 n}\left(2,5-\mathrm{Me}_{2}\right.$ pyz $=2,5$-dimethylpyrazine," New Journal of Chemistry, vol. 26, pp. 523-525, 2002.

[93] J. L. Manson, Q. Z. Huang, J. W. Lynn et al., "Long-range magnetic order in $\mathrm{Mn}\left[\mathrm{N}(\mathrm{CN})_{2}\right]_{2}$ (pyz) \{pyz = pyrazine $\}$. Susceptibility, magnetization, specific heat, and neutron diffraction 
measurements and electronic structure calculations," Journal of the American Chemical Society, vol. 123, no. 1, pp. 162-172, 2001.

[94] P. M. van der Werff, S. R. Batten, P. Jensen, B. Moubaraki, and K. S. Murray, "Cation templation of anionic metal dicyanamide networks," Inorganic Chemistry, vol. 40, pp. 1718-1722, 2001.

[95] H. L. Sun, Z. M. Wang, and S. Gao, "Synthesis, crystal structures, and magnetism of cobalt coordination polymers based on dicyanamide and pyrazine-dioxide derivatives," Inorganic Chemistry, vol. 44, no. 7, pp. 2169-2176, 2005.

[96] J. Curély, F. Lloret, and M. Julve, PhysicalReview B, vol. 58, p. 1465, 1988.

[97] D. Armentano, G. de Munno, F. Guerra, M. Julve, and F. Lloret, "Ligand effects on the structures of extended networks of dicyanamide-containing transition-metal ions," Inorganic Chemistry, vol. 45, no. 12, pp. 4626-4636, 2006. 

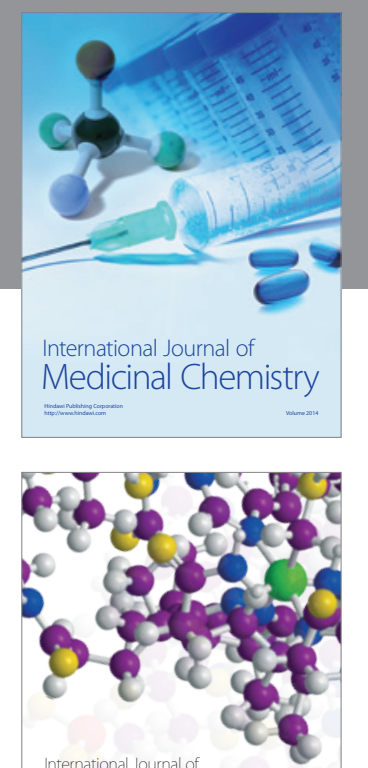

\section{Carbohydrate} Chemistry

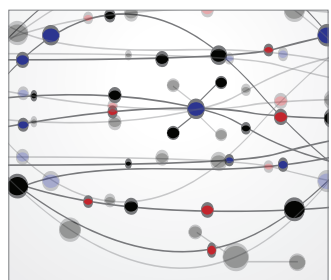

The Scientific World Journal
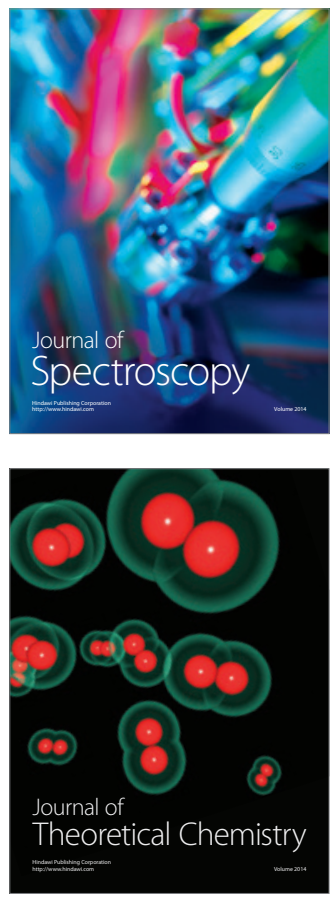
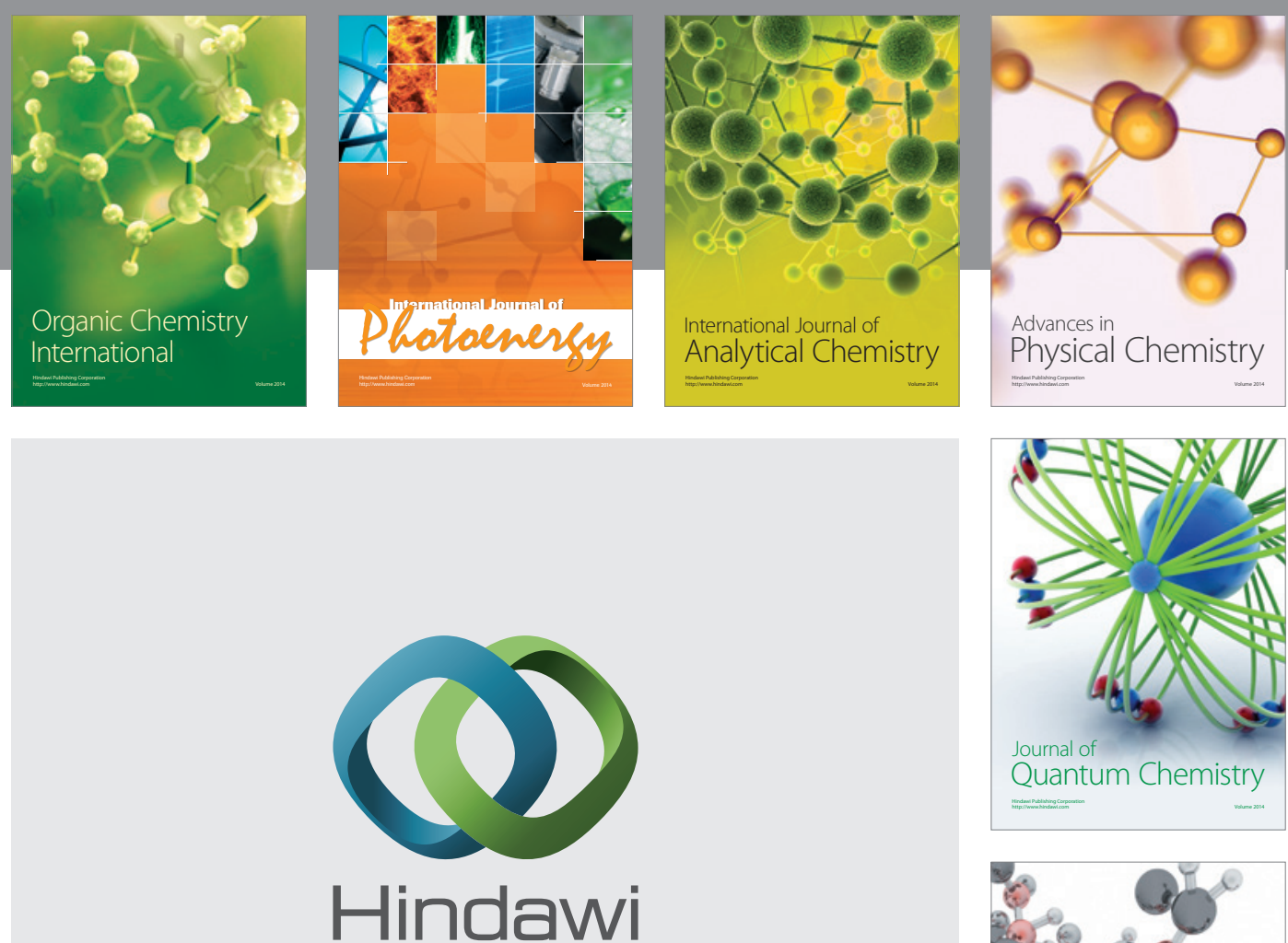

Submit your manuscripts at

http://www.hindawi.com

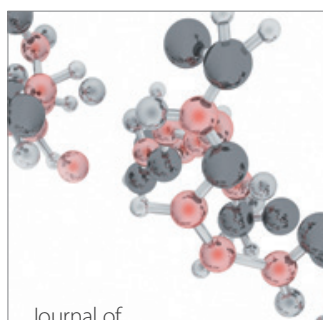

Analytical Methods

in Chemistry

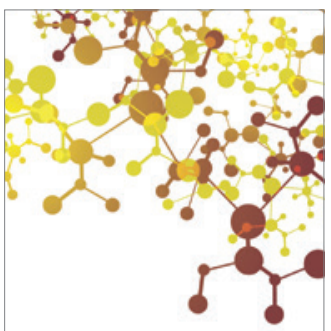

Journal of

Applied Chemistry

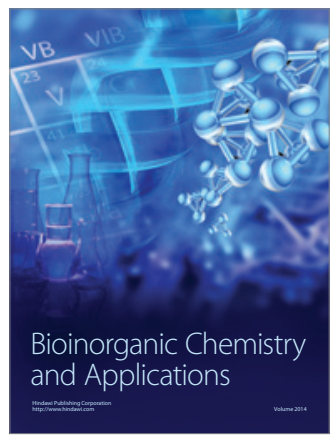

Inorganic Chemistry
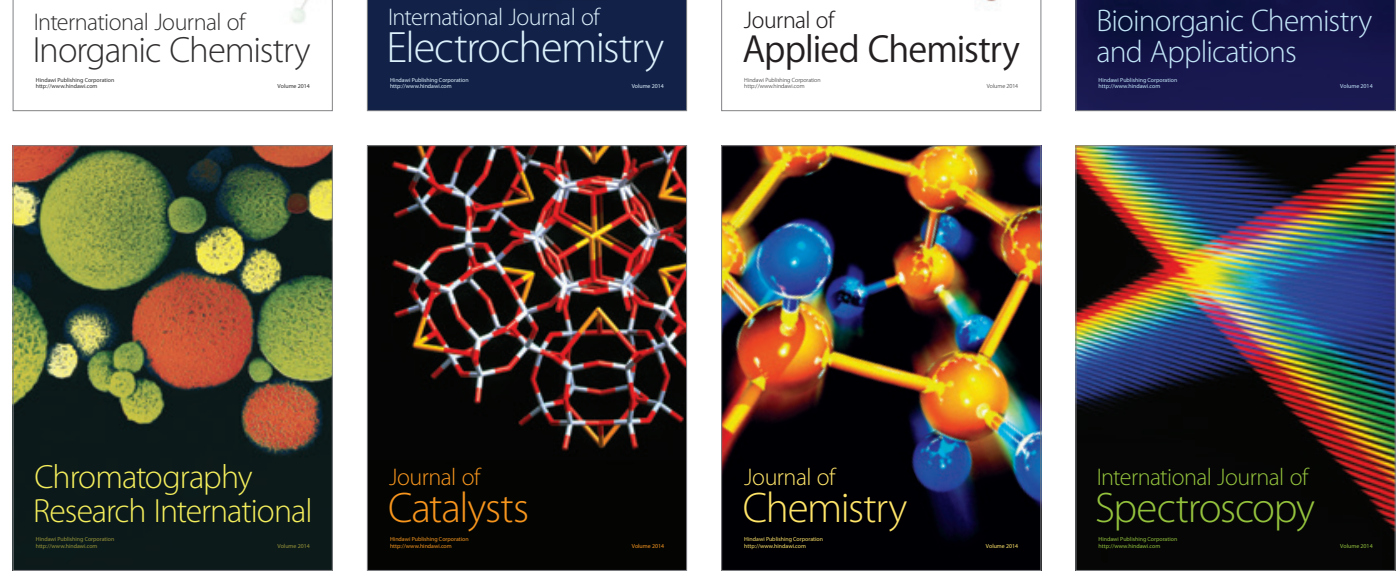